\title{
Index of CD34+ Cells and Mononuclear Cells in the Bone Marrow of Spinal Cord Injury Patients of Different Age Groups: A Comparative Analysis
}

\author{
Vidyasagar Devaprasad Dedeepiya,, ${ }^{1,2}$ Yegneswara Yellury Rao, ${ }^{3}$ \\ Gosalakkal A. Jayakrishnan, ${ }^{4}$ Jutty K. B. C. Parthiban, ${ }^{1}$ Subramani Baskar, ${ }^{1,2}$ \\ Sadananda Rao Manjunath, ${ }^{1,2}$ Rajappa Senthilkumar, ${ }^{1,2}$ and Samuel J. K. Abraham ${ }^{1,5}$ \\ ${ }^{1}$ Division of Translational Medicine, Nichi-In Centre for Regenerative Medicine (NCRM), C 16 \& 17, \\ Vijaya Health Centre Premises, 175 NSK Salai, Vadapalani, Chennai-600026, Tamil Nadu, India \\ ${ }^{2}$ Department of Biotechnology, Acharya Nagarjuna University, Nagarjuna Nagar, Guntur 522 510, India \\ ${ }^{3}$ Department of Medicine, KG Hospital, Arts College Road, Coimbatore 641018, India \\ ${ }^{4}$ Department of Cardiothoracic Surgery, Omega Hospital, Mangalore, Mahaveera Circle, Kankanady, Mangalore 575002, India \\ ${ }^{5}$ Department of Surgery, Faculty of Medicine, University of Yamanashi, 1110 Shimokato, Yamanashi, Chuo 409-3898, Japan \\ Correspondence should be addressed to Samuel J. K. Abraham, drabrahamsj@ybb.ne.jp
}

Received 15 February 2012; Revised 25 April 2012; Accepted 3 May 2012

Academic Editor: Mark R. Litzow

Copyright () 2012 Vidyasagar Devaprasad Dedeepiya et al. This is an open access article distributed under the Creative Commons Attribution License, which permits unrestricted use, distribution, and reproduction in any medium, provided the original work is properly cited.

\begin{abstract}
Introduction. Recent evidence of safety and efficacy of Bone Marrow Mononuclear Cells (BMMNC) in spinal cord injury makes the Bone Marrow (BM) CD34+ percentage and the BMMNC count gain significance. The indices of BM that change with body mass index and aging in general population have been reported but seldom in Spinal Cord Injury (SCI) victims, whose parameters of relevance differ from general population. Herein, we report the indices of BMMNC in SCI victims. Materials and Methods. BMMNCs of 332 SCI patients were isolated under GMP protocols. Cell count by Trypan blue method and CD34+ cells by flow cytometry were documented and analysed across ages and gender. Results. The average BMMNC per ml in the age groups 0-20, 21-40, 41-60, and 61-80 years were 4.71, 4.03, 3.67, and 3.02 million and the CD34+ were $1.05 \%, 1.04 \%, 0.94 \%$, and $0.93 \%$ respectively. The decline in CD34+ was sharp between 20-40 and 40-60 age groups. Females of reproductive age group had lesser CD34+. Conclusion. The BMMNC and CD34+ percentages decline with aging in SCI victims. Their lower values in females during reproductive age should be analysed for relevance to hormonal influence. This study offers reference values of BMMNC and CD34+ of SCI victims for successful clinical application.
\end{abstract}

\section{Introduction}

With a reported global prevalence ranging from 236 to 1009 per million [1], Spinal Cord Injury (SCI) continues to be a devastating problem with no definite solutions. Spinal Cord Injury may be due to both traumatic (e.g., road traffic accidents) or nontraumatic causes (e.g., infections, congenital causes, tumours, etc.). In traumatic spinal cord injury, primary injury caused by compression or traction causes direct injury to neural elements due to the displaced bone fragments, ligaments, and disc material which leads to damage of the axons, neural cell bodies, and blood vessels. The spinal cord swells occupying the entire diameter of the spinal canal and ischemia results. The ischemia by releasing toxins gives rise to a cascade of secondary events ultimately leading to damage of the neighbouring healthy neurons [2]. The current mainline approaches of treatment involve removal of the bone fragments or other components to decompress the swollen spinal cord with the primary approach being limiting the secondary damage, followed by rehabilitation to assist in spontaneous recovery [2]. However the recovery is only limited in most of the cases. Hence, newer therapeutic 
options are being explored which might aid in complete recovery of the injured spinal cord. In this context, in addition to pharmacological treatment for improving the regeneration of the neurons using antiapoptotic agents, growth factors, and so forth [2], cell-based therapies are being sought for, as a promising approach to the condition. Several works of literature have reported the application of Bone Marrow Mononuclear Cell transplantation in Spinal Cord Injury with varying success rates [3-12]. It should be noted that CD34+ Hematopoietic Stem Cell (HSC) quantity is important because it has been reported that CD34 + cell quantity is an important dosage indicator for the success of BMMNC cell therapy [13]. Since clinical success of therapy might be attributed to the cell composition, an analysis of the same is needed to predict the success of such cell-based therapies. There are several works of literature on the composition of progenitor cell components in blood and bone marrow of healthy donors [14-16], but seldom in patients. In particular, the composition and other characteristics of bone marrow stem cells in spinal cord injury patients might be different from healthy individuals and even in patients with other kinds of organ dysfunctions, because spinal cord injury patients differ from the rest, in characteristics such as sedentary life style, body mass index, changes in neuronal control over hematopoiesis after the injury, and so forth [17-20]. This revelation can be drawn from works of literature like the study by Chernykh et al., which has compared the phenotypical and functional characteristics of bone marrow stem cells from spinal cord injury patients and healthy donors. In that study, it is stated that the percentage of CD34+CD38- hematopoietic stem cells is elevated in these patients compared to donors [21]. Also, Wright et al. published a study in which they examined the growth in cell culture of MSCs isolated from individuals with SCI, compared with non-SCI donors and they reported that age, level of spinal injury, and cell-seeding density were all related to the growth kinetics of MSC cultures in vitro [22].

In this study, we present a retrospective analysis of the data on BMMNC and HSC quantity obtained from 332 spinal cord injury patients admitted for autologous BMSC application over five years and we arrived at various indices such as BMMNC present in per $\mathrm{mL}$ of $\mathrm{BM}$ and percentage of CD34+ HSC in these patients.

\section{Materials and Methods}

2.1. Patients. All the procedures were carried in accordance with the local and national regulatory guidelines. The procedures followed were in accordance with the ethical standards described by the Helsinki Declaration.

Three hundred and thirty-two bone marrow samples were included in the study. The bone marrow samples were obtained from spinal cord injury patients who were admitted to various hospitals for autologous application of BMMNC, after ethics committee approvals from the respective hospitals and after proper informed consent. Males were predominant, with a total of 267 against 65 females. The age of the patients ranged from 1 to 76 years. The level of injury varied, ranging from $\mathrm{C} 1$ to $\mathrm{S} 1$ level. The samples were grouped into four based on the age: 0 to 20 years-Group I, 21-40 years-Group II, 41-60 years-Group III and 61-80 yearsGroup IV. The time from injury to stem cell application ranged from one month to twenty years. The samples were included only if the patients' vital parameters were in the normal physiological range and they did not have any other abnormalities in their blood forming system such as an associated autoimmune disease or malignancy.

2.2. Bone Marrow Aspiration and Cell Isolation. The cell processing was done in a single institute for all the five years. Ninety to hundred $\mathrm{mL}$ (average $95 \mathrm{~mL}$ ) of bone marrow aspirated from the ileac crest in all the patients was transported in an anticoagulant solution under cold chain and on reaching the lab the samples were subjected to processing immediately. The samples were processed under cGMP SOP's class 10000 clean room and class 100 Biosafety cabinets. The samples were subjected to Ficoll gradient centrifugation procedure and the BMMNCs were collected by removing the buffy coat. The viability of the cells was checked using Trypan blue and cell count was done by using Neubaur's Haemocytometer. The quantity of BMMNC per $\mathrm{mL}$ was calculated. A portion of the isolated BMMNCs from each sample was sent for Immunophenotyping (IP Typing) analysis to analyze the quantity of CD34+ cells by flow cytometry (BD FACS Calibur, USA).

\section{Results}

The results are presented in Table 1. The average BMMNC per $\mathrm{mL}$ in patients of age group 0-20 years was 4.71 million; in 21-40 years it was 4.03 million; in $41-60$ years it was 3.67 million; in 61-80 it was 3.02 million. The average BMMNC per $\mathrm{mL}$ in all the 332 patients ranged from a minimum of 1.47 million to a maximum of 15.36 million. The percentage of CD34+ cells in those patients belonging to the age group of 0-20 years was 1.05; in 21-40 year group 1.04; in 41-60 year group 0.94; in 61-80 year group 0.93. The average BMMNC per $\mathrm{mL}$ in males was 3.86 million, while in females it was 3.66 million. The average CD34\% in males was 1.01, while in females it was 0.925. A slight decrease in the BMMNC per $\mathrm{mL}$ and $\mathrm{CD} 34+$ quantity was observed with increase in the age but they were not stastically significant (Figures 1 and 2). The decline in CD34+ was sharp between the groups 2040 and 40-60, and particularly, females in the reproductive age group had a lesser CD34+ HSC and BMMNC quantity compared to males of similar age. Clinical observations of the patients till date showed that there are no adverse reactions in any of the patients and further followup is underway.

\section{Discussion}

Bone marrow mononuclear cell transplantation for spinal cord injury is a promising approach with several studies reporting varying efficacies in animal models and in humans. [3-12]. The mechanisms by which these cells contribute to spinal cord injury repair are still not understood to the fullest. The proposed mechanisms by which the injected cells may act are by transdifferentiation into neuronal lineage, 


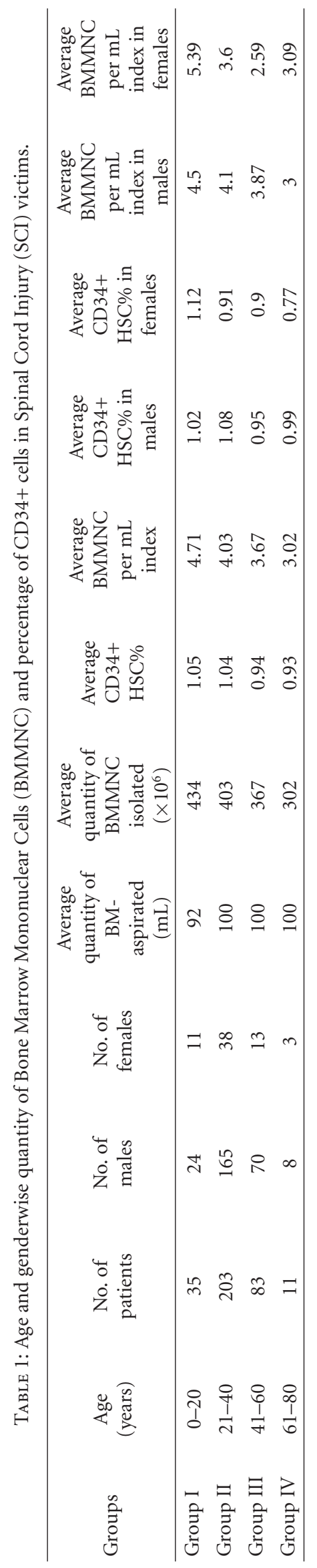




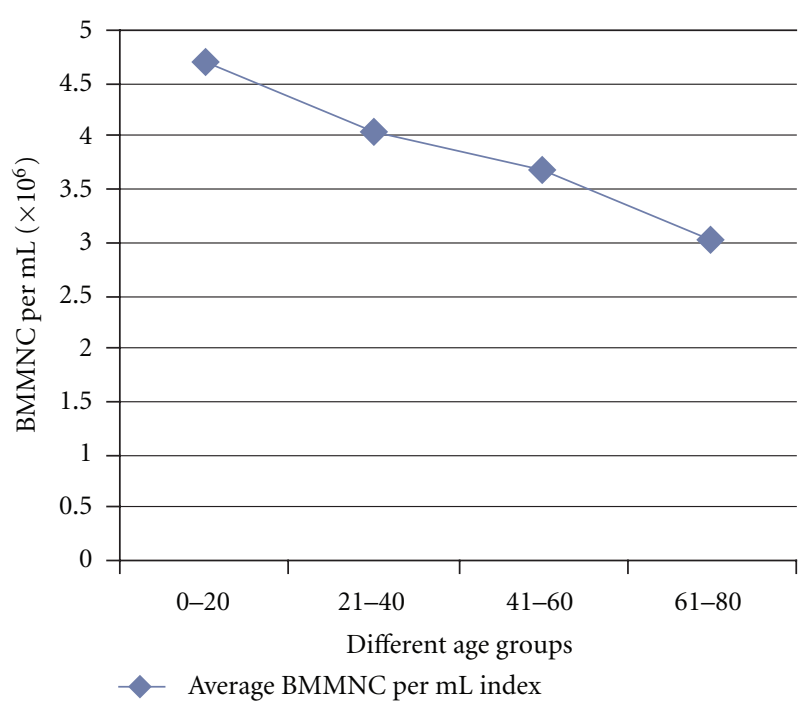

Figure 1: Average quantity of Bone Marrow Mononuclear Cells (BMMNC) per $\mathrm{mL}$ across various age groups of bone marrow samples from Spinal Cord Injury (SCI) victims.

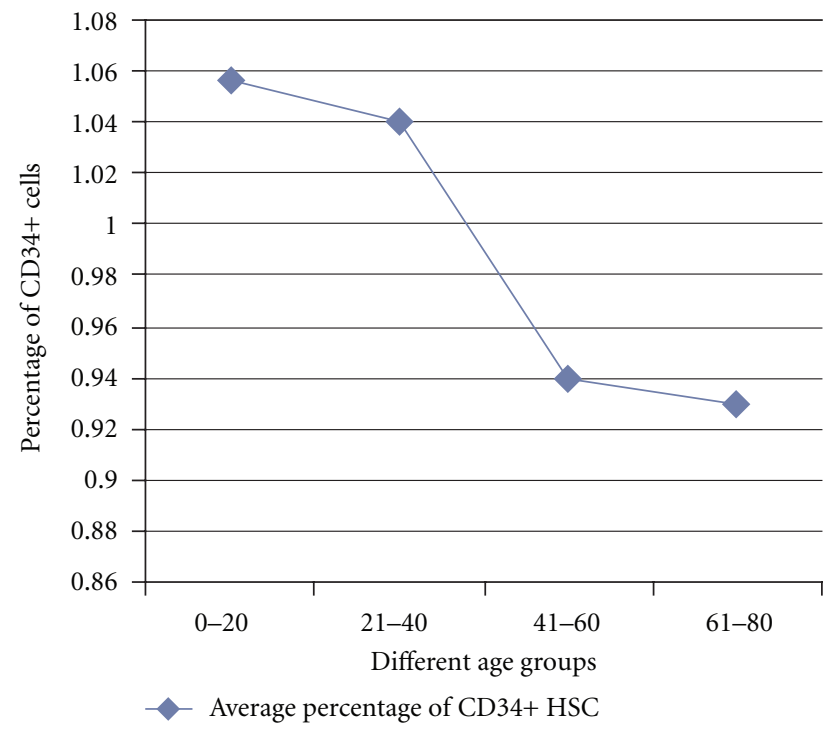

Figure 2: Average quantity of CD34+ Hematopoietic Stem Cell (HSC) percentage across various age groups of bone marrow samples from Spinal Cord Injury (SCI) victims.

inducing cells in the region neighbouring the spinal cord injury to regenerate or replace the injured neurons, secretion of neurotrophic factors, and altering the in vivo milieu in favour of regeneration [23]. Though BMMNC is a comprehensive cell population, particular importance has been attached to the CD34+ HSC quantity as several studies have reported that it is an important dosage indicator for success of bone marrow cell therapy [7-9].

There are several works of literature on the quantity of Mononuclear Cells (MNCs) and CD34+ HSCs in per mL or the whole bone marrow. Table 2 gives the details of some of the literature on such parameters based on our search. It has been found that works of literature reporting such data are very limited, which can serve as a valuable reference on the quantity of BMMNC or CD34+ HSC across different age groups of individuals, especially in spinal cord injury patients. Chernykh et al. have reported a similar study in spinal cord injury patients but the sample size is limited [21]. Our study on samples obtained from 332 spinal cord injury victims can thus serve as a very valuable literature for future studies on evaluation of quantity of bone marrow for optimal cell isolation and dosing studies on stem cells in spinal cord injury.

Body mass index has a significant role to play in progenitor cell population and their mobilization with majority of the reports indicating that higher BMI and obesity are associated with increased CD34+ cell counts $[16,24,25]$. It is noticed that spinal cord injury victims generally have higher BMI due to their sedentary lifestyle and higher food intake [17-19]. Hence, it is logical to expect the CD34+ cell percentage to be higher in them. Another reason stated for higher CD34+ HSC count in spinal cord injury patients is the increase in the proliferative potential of CD34+ HSCs rising from the impaired innervation resulting in attenuation of negative control over HSC proliferation from the nervous system [21]. Spinal cord injury leads to secondary complications like alterations in lipid and glucose metabolism, which may lead to increased body fat. Chronic spinal cord injury also has been shown to increase the level of cytokines and interleukins thereby leading to increased inflammatory activity, which may also be a possible mechanism behind the increased CD34+ HSC proliferation in spinal cord injury. The increased progenitor levels in spinal cord injury may have a positive effect in improving tissue repair and regeneration in spinal cord injury following stem cell application [20]. A study in a chick embryo concluded that HSCs produce neurons more efficiently in a regenerating spinal cord due to favourable microenvironment [26]. All these studies imply that autologous HSCs from the spinal cord injury patients can be of a therapeutic advantage in these patients. However, increased inflammation combined with decreased immunity observed in spinal cord injury patients may also lead to increased risk of cancer incidence in these patients as reported [20]. The average BMMNC per $\mathrm{mL}$ and CD34+ HSC \% obtained in the present study was 3.85 million, which is relatively less compared to that reported by Chernykh et al. [21], but the number of study subjects is substantially high in the present study. Also, the large difference in age, level of injury, and time of bone marrow harvest since time of injury between the patients may influence the average values obtained. The present study provides information of the index of quantity of BMMNC present per $\mathrm{mL}$ of bone marrow in different age groups of patients with spinal cord injury which is a worthy reference for future studies.

The influence of donor characteristics on the yield of BMMNC and the percentage of hematopoietic stem cells in the BMMNC population have been the objective of various studies described in works of literature $[15,16]$. Variables such as gender, genetics, sleep, and circadian rhythm have been found to influence the quantity and other 
TAble 2: Data of the quantity of Bone Marrow Mononuclear Cells (BMMNC) and CD34+ Hematopoietic Stem Cells (HSC) from the literatures based on our search.

\begin{tabular}{|c|c|c|c|c|c|c|c|c|}
\hline $\begin{array}{l}\text { S. } \\
\text { No. }\end{array}$ & Author & $\begin{array}{c}\text { Year of } \\
\text { Publication }\end{array}$ & $\begin{array}{c}\text { No. of } \\
\text { Samples }\end{array}$ & $\begin{array}{l}\text { Patients or } \\
\text { Donors }\end{array}$ & $\begin{array}{c}\text { Parameters } \\
\text { assessed }\end{array}$ & $\begin{array}{c}\text { Mean Quantity of } \\
\mathrm{MNC} / \mathrm{ml}\end{array}$ & $\begin{array}{c}\text { Mean } \\
\text { CD34\% }\end{array}$ & $\begin{array}{c}\text { Mean CD34+ } \\
\text { cell count }\end{array}$ \\
\hline 1 & Ema et al. [32] & 1990 & 12 & Donors & CD34\% & NA & $\begin{array}{l}1.05 \% \pm \\
0.44 \% *\end{array}$ & \\
\hline 2 & $\begin{array}{c}\text { Chernykh et al. } \\
{[21]}\end{array}$ & 2006 & 10 & Donors & $\begin{array}{l}\text { MNC, count and } \\
\text { CD34\% }\end{array}$ & $7.5 \pm 2.2 \times 10^{6}$ & $\begin{array}{c}5.40 \pm \\
1.35\end{array}$ & \\
\hline 3 & $\begin{array}{c}\text { Chernykh et al. } \\
{[21]}\end{array}$ & 2006 & 16 & $\begin{array}{l}\text { Spinal Cord } \\
\text { injury Patients }\end{array}$ & $\begin{array}{l}\text { MNC count and } \\
\text { CD34 percentage }\end{array}$ & $11.0 \pm 1.1 \times 10^{6}$ & $5.4 \pm 0.6$ & \\
\hline 4 & $\begin{array}{l}\text { Mohamadnejad } \\
\text { et al. [33] }\end{array}$ & 2007 & 4 & $\begin{array}{l}\text { Liver Cirrhosis } \\
\text { patients }\end{array}$ & $\begin{array}{l}\mathrm{MNC} \text { and } \mathrm{CD} 34 \\
\text { percentage }\end{array}$ & $3.13 \times 10^{8}$ & & $5.25 \times 10^{6}$ \\
\hline 5 & $\begin{array}{l}\text { Hernández et al. } \\
\qquad 34]\end{array}$ & 2007 & 12 & $\begin{array}{l}\text { Critical limb } \\
\text { Ischemia patients }\end{array}$ & $\begin{array}{l}\text { MNC and CD34+ } \\
\text { cell counts }\end{array}$ & $\begin{array}{l}1.74 \pm 1.23 \times 10^{9} \text { in } \\
\text { group A (Separation } \\
\text { done using blood cell } \\
\text { separator) and } 2.47 \pm \\
1.48 \times 10^{9} \text { in group B } \\
\text { (Separation done by } \\
\text { density gradient by } \\
\text { Ficoll-Hypaque) }\end{array}$ & & $\begin{array}{l}8.14 \pm 6.67 \times \\
10^{7} \text { in group } \\
\mathrm{A} \text { and } 7.90 \pm \\
5.46 \times 10^{7} \text { in } \\
\quad \text { group B }\end{array}$ \\
\hline 6 & $\begin{array}{c}\text { Kaparthi et al. } \\
{[35]}\end{array}$ & 2008 & 5 & $\begin{array}{l}\text { Cardiac Disease } \\
\text { patients }\end{array}$ & $\begin{array}{l}\text { MNC and CD34+ } \\
\text { cell count and } \\
\text { percentage }\end{array}$ & $9.16 \times 10^{7}$ & 0.348 & $3.68 \times 10^{5}$ \\
\hline 7 & $\begin{array}{l}\text { Harting et al. } \\
{[36]}\end{array}$ & 2009 & 36 & $\begin{array}{l}10 \text { paediatric and } \\
26 \text { adult } \\
\text { Non-cancer } \\
\text { patients }\end{array}$ & MNC counts & $\begin{array}{l}\text { Paediatric patients } \\
-2.1 \times 10^{6} / \mathrm{mL} \text { and in } \\
\text { older patients }-3.2 \times \\
10^{6} / \mathrm{mL}\end{array}$ & & \\
\hline 8 & Zhang et al. [16] & 2010 & 104 & Donors & $\begin{array}{l}\text { CD34+ cell count } \\
\text { and Circulating } \\
\text { Immature Cells } \\
\text { (CIC) count }\end{array}$ & $\begin{aligned} \mathrm{CIC}= & 9 \cdot 4(4 \cdot 3-21 \cdot 1) \\
& \times 10^{9} \mathrm{~L}^{-1}\end{aligned}$ & & $\begin{array}{c}\text { Total CD34+ } \\
\text { cell count } \\
\left(\times 10^{6}\right) \text { is } \\
395 \cdot 7 \\
(102-1282)\end{array}$ \\
\hline 9 & $\begin{array}{l}\text { Perseghin and } \\
\text { Incontri [37] }\end{array}$ & 2010 & 10 & $\begin{array}{l}\text { Patients-nine } \\
\text { with chronic } \\
\text { GvHD and one } \\
\text { with bullous } \\
\text { pemphigoid }\end{array}$ & MNC & $\begin{array}{l}5.9 \pm 2.19 \times 10^{9} \text { in } \\
\text { the separation done } \\
\text { by Spectra cell } \\
\text { separator and } 5.29 \pm \\
2.39 \times 10^{9} \text { in the } \\
\text { separation done by } \\
\text { Amicus cell separator }\end{array}$ & & \\
\hline
\end{tabular}

*\% mentioned is that of gated cells.

characteristics of BMMNC and CD34+ cells [27-31]. We have assessed the quantity of BMMNC and CD34+ HSCs in relation to age and gender in this study.

The slight decrease in CD34+ cell quantity with increasing age in our study, though statistically not significant (Figure 2), needs thorough analysis taking into consideration other parameters of significance, which are beyond the scope of this study. On the influence of age on BMMNC and CD34+ cell count, there are conflicting reports as in few of the works of literature; it has been reported that there is indeed a decrease in CD34+ cell quantity with increasing age $[30,31,38-40]$, but few other works have indicated that though the functionality of HSC decreases with increasing age, there is not much difference in the HSC number with increasing age $[41,42]$ including reports that there is an increase in multipotent $\mathrm{CD} 34(+) \mathrm{CD} 38(-)$ population in the bone marrow of elderly individuals above 70 years of age. Also, in the same study it was reported that CD34(+) CD38(+) CD90(-) CD45RA(+/-) CD10(-) and CD34(+) $\mathrm{CD} 33(+)$ myeloid progenitors persist at the same level in the bone marrow, while the frequency of early $\mathrm{CD} 34(+)$ CD38(+) CD90(-) CD45RA(+) CD10(+) and committed $\mathrm{CD} 34(+) \mathrm{CD} 19(+)$ B-lymphoid progenitors decreases with age [43]. Cho et al. suggests that there are several subsets in HSCs, which are very different from each other, each possessing distinct self-renewal capacities, differentiation abilities, life span, and repopulation kinetics and with aging, lymphoid-biased HSCs are decreased, while the myeloidbiased HSCs accumulate, indicating that aging instead of affecting the HSC in general changes the clonal composition of the HSC compartment [44]. In another study, it was reported that in hematopoietic stem cell transplantation (HSCT), 0-20 year-old donors were yielding relatively higher Mesenchymal Stem Cells (MSCs) in shorter duration and 
their biological characteristics were superior to that of older age groups [40]. It should be understood that in our study the CD34+ cells as a whole have been studied and not the clonal proliferative capability. It has been reported that there is a strong genetic component that contributes to the changes in stem cell numbers during aging [30]. Thus, it will be ideal to analyse not only the CD34+ cell quantity as a whole, but also the clonal populations in the different age groups of such patients as it will serve as an accurate indicator of the variations in bone marrow functionality with increasing age. This analysis will help in predicting the success of cell transplantation in different age groups of patients with spinal cord injury.

On the influence of gender on BMMNC and CD34+ HSC, in an article by Newman et al. on the yield of nucleated cells from marrow derived from cadaveric vertebral bodies, it has been reported that female donors yielded lower cell numbers independent of age and male donors less than 30 years of age yielded the highest number of cells [27]. There are also studies to show that male infants have significantly higher median CD34+ cell concentrations than female infants, which are reflected in an increased number of colony-forming cells, erythroblastic colonies, and granulocyte-macrophage colonies in their peripheral blood $[45,46]$. It has also been suggested, based on literary evidence, that " $17 \beta$-estradiol exerts negative influence on the production of B-lineage cells by modifying the differentiation, proliferation, and survival of early B-cell precursors and androgens exert an inhibitory effect on B lymphopoiesis but enhance erythropoietic differentiation and thrombocytopoiesis." [46]. Thus, it can be understood that sex hormones may influence HSC and hematopoiesis but the effects of different sex hormones on individual cell populations of the bone marrow need further analysis. In our study, a steady decrease in the BMMNC per $\mathrm{mL}$ can be seen with increasing age but it is not of statistical significance. The decline in CD34+ was sharp between the 20-40 and the 40-60 age groups and particularly females in the reproductive age group had a lesser CD34 and BMMNC quantity compared to males though statistically insignificant. The lesser BMMNC per $\mathrm{mL}$ and CD34+ HSC in females compared to males might be due to the influence of sex hormones, which exert their effects on hematopoiesis in the bone marrow and this effect of female sex hormones will possibly be more pronounced in the reproductive age group of females appreciated by the sharp decline of BMMNC per $\mathrm{mL}$ and CD34+ HSC in Figures 3 and 4. However, the number of females is several times lesser than the number of males in each age group in this study and hence, further investigation on these lines is warranted in studies with equal number of samples from both the genders.

Clinical observations in the patients showed that there were no adverse reactions in any of the patients. The interim results of six-month followup on 108 patients out of these 332 patients revealed that " $14.11 \%$ of patients reported at least 2 grades of improvement in motor power and $4.7 \%$ of patient were able to walk independently. $16.47 \%$ of patients reported subjective sensory improvement; none of the patients had abnormal sensations such as Allodynia

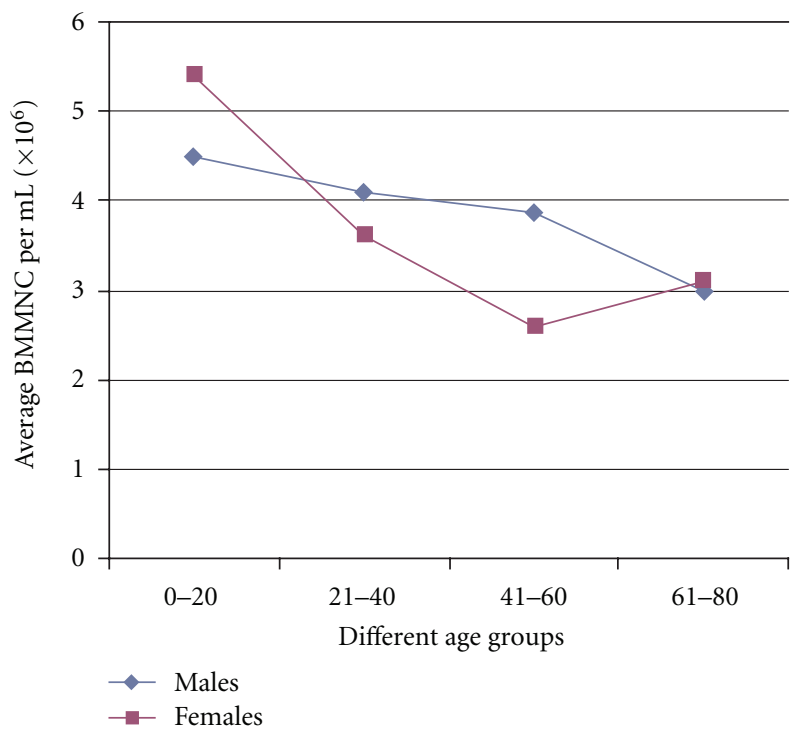

FIgURE 3: Comparison of average quantity of Bone Marrow Mononuclear Cells (BMMNC) per mL between male and female Spinal Cord Injury (SCI) victims.

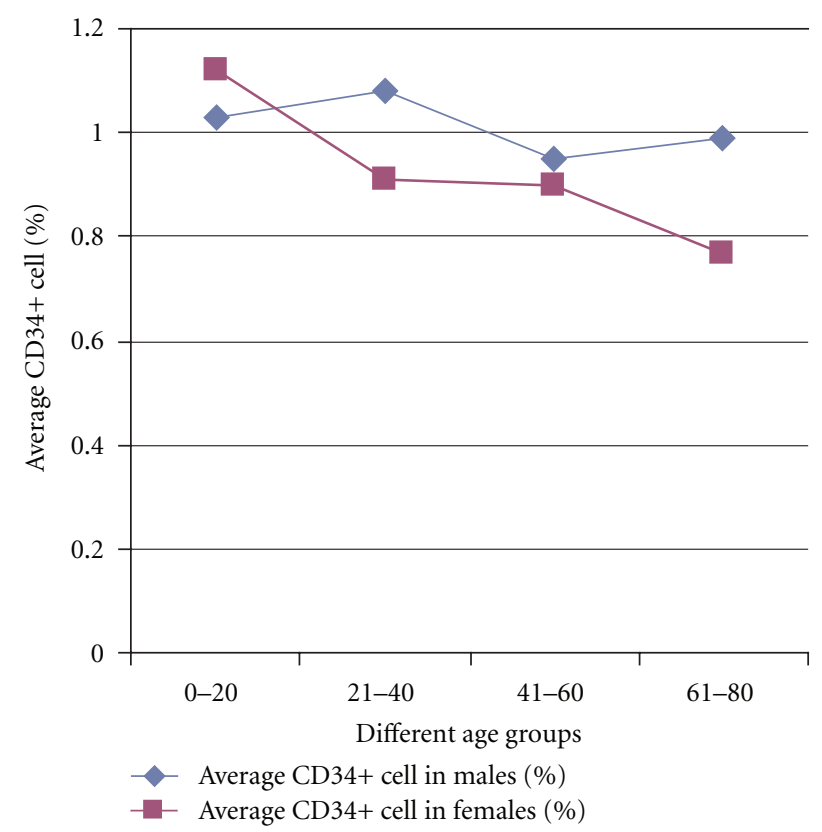

Figure 4: Comparison of CD34+ Hematopoietic Stem Cell (HSC) percentage between male and female Spinal Cord Injury (SCI) victims.

and $9.41 \%$ of patients had improvement as documented by Urodynamic studies." [47]. Since the main aim of the present study is evaluation of characteristics of the bone marrow in these patients, results of clinical evaluation will be out of scope of the current study.

The two indices described above, namely, the BMMNC index, that is, quantity of BMMNC per $\mathrm{mL}$ of bone marrow and the CD34+ cell index, that is, percentage of CD34+ cells in a given bone marrow sample can also be used for 
quantification studies to assess the approximate quantity of bone marrow to be harvested from spinal cord injury patients for therapeutic application. Though CD34+ cell quantity is widely used as a predictor of engraftment, a recent study done on 435 Cord Blood Transplants has suggested that the CFU dose is a better predictor of engraftment [48]. Further studies should be done on analysing this triad of parameters: the BMMNC per $\mathrm{mL}, \mathrm{CD} 34+$ cell quantity per $\mathrm{mL}$, and $\mathrm{CFU}$ in bone marrow samples in various age groups of patients with spinal cord injury also with healthy donors to arrive at data, based on which this triad can be made as a gold standard testing method in accurately predicting the functionality and quality of the bone marrow for application in spinal cord injuries.

\section{Conclusion}

We have described two useful indices for assessment of BMMNC and CD34+ HSC quantity in bone marrow based on data obtained from spinal cord injury patients with normal vital physiological parameters. In our evaluation, the average BMMNC per $\mathrm{mL}$ and the percentage of $\mathrm{CD} 34+$ cells show a decline with aging in spinal cord injury victims of both males and females. The BMMNC and CD34+ HSC are relatively lower in females than males and there is a sharp decline of CD34+ HSC in females in the reproductive age group. The fact that the characteristics of BMMNCs and HSCs will differ in spinal cord injury patients compared to normal patients due to the differences in lifestyle and other parameters makes these findings important, as the values of BMMNC and CD34+ HSC from this study may be used as a reference for future studies. The decreased BMMNC and CD34+ HSC in females will have to be analysed for their relevance to hormonal influence. The Colony Forming Unit (CFU) analysis, which is more relevant as physiological indicator, when assessed may throw further light and add significance.

\section{Acknowledgments}

The authors acknowledge Dr. Ryuji Hata for his technical advice, Dr. Preethy Senthilkumar for her assistance in preparation of the paper, M/S Hope Foundation (Trust) Chennai, India for funding the study.

\section{References}

[1] R. A. Cripps, B. B. Lee, P. Wing, E. Weerts, J. MacKay, and D. Brown, "A global map for traumatic spinal cord injury epidemiology: towards a living data repository for injury prevention," Spinal Cord, vol. 49, no. 4, pp. 493-501, 2011.

[2] J. W. McDonald and C. Sadowsky, "Spinal-cord injury," The Lancet, vol. 359, no. 9304, pp. 417-425, 2002.

[3] A. Sharma, N. Gokulchandran, G. Chopra et al., "Administration of autologous bone marrow-derived mononuclear cells in children with incurable neurological disorders and injury is safe and improves their quality of life," Cell Transplantation, vol. 21, supplement 1, pp. S79-S90, 2012.
[4] A. F. Samdani, C. Paul, R. R. Betz, I. Fischer, and B. Neuhuber, "Transplantation of human marrow stromal cells and mononuclear bone marrow cells into the injured spinal cord: a comparative study," Spine, vol. 34, no. 24, pp. 2605-2612, 2009.

[5] E. Syková, A. Homola, R. Mazanec et al., "Autologous bone marrow transplantation in patients with subacute and chronic spinal cord injury," Cell Transplantation, vol. 15, no. 8-9, pp. 675-687, 2006.

[6] T. Yoshihara, M. Ohta, Y. Itokazu et al., "Neuroprotective effect of bone marrow-derived mononuclear cells promoting functional recovery from spinal cord injury," Journal of Neurotrauma, vol. 24, no. 6, pp. 1026-1036, 2007.

[7] J. B. William, R. Prabakaran, S. Ayyappan et al., "Functional recovery of spinal cord injury following application of intralesional bone marrow mononuclear cells embedded in polymer scaffold-two year follow-up in a Canine," Journal of Stem Cell Research \& Therapy, vol. 1, p. 110, 2011.

[8] H. C. Park, Y. S. Shim, Y. Ha et al., "Treatment of complete spinal cord injury patients by autologous bone marrow cell transplantation and administration of granulocyte-macrophage colony stimulating factor," Tissue Engineering, vol. 11, no. 5-6, pp. 913-922, 2005.

[9] F. Callera and R. X. Do Nascimento, "Delivery of autologous bone marrow precursor cells into the spinal cord via lumbar puncture technique in patients with spinal cord injury: a preliminary safety study," Experimental Hematology, vol. 34, no. 2, pp. 130-131, 2006.

[10] S. H. Yoon, Y. S. Shim, H. P. Yong et al., "Complete spinal cord injury treatment using autologous bone marrow cell transplantation and bone marrow stimulation with granulocyte macrophage-colony stimulating factor: phase I/II clinical trial," Stem Cells, vol. 25, no. 8, pp. 2066-2073, 2007.

[11] H. Deda, M. C. Inci, A. Kurekçi et al., "Treatment of chronic spinal cord injured patients with autologous bone marrowderived hematopoietic stem cell transplantation: 1-year follow-up," Cytotherapy, vol. 10, no. 6, pp. 565-574, 2008.

[12] L. F. Geffner, P. Santacruz, M. Izurieta et al., "Administration of autologous bone marrow stem cells into spinal cord injury patients via multiple routes is safe and improves their quality of life: comprehensive case studies," Cell Transplantation, vol. 17, no. 12, pp. 1277-1293, 2008.

[13] S. Yasuhara, Y. Yasunaga, T. Hisatome et al., "Efficacy of bone marrow mononuclear cells to promote bone regeneration compared with isolated CD34+ cells from the same volume of aspirate," Artificial Organs, vol. 34, no. 7, pp. 594-599, 2010.

[14] D. F. Stroncek, M. E. Clay, J. Smith et al., "Composition of peripheral blood progenitor cell components collected from healthy donors," Transfusion, vol. 37, no. 4, pp. 411-417, 1997.

[15] W. Bouwmeester, M. M. Fechter, M. W. Heymans, J. W. R. Twisk, L. J. Ebeling, and A. Brand, "Prediction of nucleated cells in bone marrow stem cell products by donor characteristics: a retrospective single centre analysis," Vox Sanguinis A, vol. 98, no. 3, pp. e276-e283, 2010.

[16] C. Zhang, X. H. Chen, X. Zhang et al., "Stem cell collection in unmanipulated HLA-haploidentical/mismatched related transplantation with combined granulocyte-colony stimulating factor-mobilised blood and bone marrow for patients with haematologic malignancies: the impact of donor characteristics and procedural settings," Transfusion Medicine, vol. 20, no. 3, pp. 169-177, 2010.

[17] S. L. Groah, M. S. Nash, I. H. Ljungberg et al., "Nutrient intake and body habitus after spinal cord injury: an analysis by sex and level of injury," Journal of Spinal Cord Medicine, vol. 32, no. 1, pp. 25-33, 2009. 
[18] Y. Chen, Y. Cao, V. Allen, and J. S. Richards, "Weight matters: physical and psychosocial well being of persons with spinal cord injury in relation to body mass index," Archives of Physical Medicine and Rehabilitation, vol. 92, no. 3, pp. 391-398, 2011.

[19] D. A. Crane, J. W. Little, and S. P. Burns, "Weight gain following spinal cord injury: a pilot study," Journal of Spinal Cord Medicine, vol. 34, no. 2, pp. 227-232, 2011.

[20] E. Kostovski, P. O. Iversen, and N. Hjeltnes, "Complications of chronic spinal cord injury," Tidsskr Nor Laegeforen, vol. 130, no. 12, pp. 1242-1245, 2010.

[21] E. R. Chernykh, E. Y. Shevela, O. Y. Leplina et al., "Characteristics of bone marrow cells under conditions of impaired innervation in patients with spinal trauma," Bulletin of Experimental Biology and Medicine, vol. 141, no. 1, pp. 117-120, 2006.

[22] K. T. Wright, W. E. Masri, A. Osman et al., "The cell culture expansion of bone marrow stromal cells from humans with spinal cord injury: implications for future cell transplantation therapy," Spinal Cord, vol. 46, no. 12, pp. 811-817, 2008.

[23] K. T. Wright, W. El Masri, A. Osman, J. Chowdhury, and W. E. B. Johnson, "Concise review: bone marrow for the treatment of spinal cord injury: mechanisms and clinical applications," Stem Cells, vol. 29, no. 2, pp. 169-178, 2011.

[24] S. H. Chen, S. H. Yang, S. C. Chu et al., "The role of donor characteristics and post-granulocyte colony-stimulating factor white blood cell counts in predicting the adverse events and yields of stem cell mobilization," International Journal of Hematology, pp. 1-8, 2011.

[25] C. F. Bellows, Y. Zhang, P. J. Simmons, A. S. Khalsa, and M. G. Kolonin, "Influence of BMI on level of circulating progenitor cells," Obesity, vol. 19, no. 8, pp. 1722-1726, 2011.

[26] O. E. Sigurjonsson, M. C. Perreault, T. Egeland, and J. C. Glover, "Adult human hematopoietic stem cells produce neurons efficiently in the regenerating chicken embryo spinal cord," Proceedings of the National Academy of Sciences of the United States of America, vol. 102, no. 14, pp. 5227-5232, 2005.

[27] H. Newman, J. A. Reems, T. H. Rigley, D. Bravo, and D. M. Strong, "Donor age and gender are the strongest predictors of marrow recovery from cadaveric vertebral bodies," Cell Transplantation, vol. 12, no. 1, pp. 83-90, 2003.

[28] Y. J. Chang, X. Y. Zhao, M. R. Huo, X. H. Luo, and X. J. Huang, "CD34 cells and T cell subsets in recombinant human granulocyte colony-stimulating factor primed bone marrow grafts from donors with different characteristics," Zhonghua Xue Ye Xue Za Zhi, vol. 29, no. 8, pp. 512-516, 2008.

[29] L. D. Guariniello, P. Vicari, K. S. Lee, A. C. de Oliveira, and S. Tufik, "Bone marrow and peripheral white blood cells number is affected by sleep deprivation in a murine experimental model," Journal of Cellular Physiology, vol. 227, no. 1, pp. 361366, 2012.

[30] G. de Haan and G. Van Zant, "Dynamic changes in mouse hematopoietic stem cell numbers during aging," Blood, vol. 93, no. 10, pp. 3294-3301, 1999.

[31] O. Tsinkalovsky, R. Smaaland, B. Rosenlund et al., "Circadian variations in clock gene expression of human bone marrow CD34+ cells," Journal of Biological Rhythms, vol. 22, no. 2, pp. 140-150, 2007.

[32] H. Ema, T. Suda, Y. Miura, and H. Nakauchi, "Colony formation of clone-sorted human hematopoietic progenitors," Blood, vol. 75, no. 10, pp. 1941-1946, 1990.

[33] M. Mohamadnejad, M. Namiri, M. Bagheri et al., "Phase 1 human trial of autologous bone marrow-hematopoietic stem cell transplantation in patients with decompensated cirrhosis," World Journal of Gastroenterology, vol. 13, no. 24, pp. 33593363, 2007.
[34] P. Hernández, L. Cortina, H. Artaza et al., "Autologous bone-marrow mononuclear cell implantation in patients with severe lower limb ischaemia: a comparison of using blood cell separator and Ficoll density gradient centrifugation," Atherosclerosis, vol. 194, no. 2, pp. e52-e56, 2007.

[35] P. L. N. Kaparthi, G. Namita, L. K. Chelluri et al., "Autologous bone marrow mononuclear cell delivery to dilated cardiomyopathy patients: a clinical trial," African Journal of Biotechnology, vol. 7, no. 3, pp. 207-210, 2008.

[36] M. T. Harting, C. S. Cox, M. C. Day et al., "Bone marrowderived mononuclear cell populations in pediatric and adult patients," Cytotherapy, vol. 11, no. 4, pp. 480-484, 2009.

[37] P. Perseghin and A. Incontri, "Mononuclear cell collection in patients treated with extracorporeal photochemotherapy by using the off-line method: a comparison between COBE Spectra AutoPbsc version 6.1 and Amicus cell separators," Journal of Clinical Apheresis, vol. 25, no. 6, pp. 310-314, 2010.

[38] I. Stelzer, R. Fuchs, E. Schraml et al., "Decline of bone marrowderived hematopoietic progenitor cell quality during aging in the rat," Experimental Aging Research, vol. 36, no. 3, pp. 359$370,2010$.

[39] H. Vaziri, W. Dragowska, R. C. Allsopp, T. E. Thomas, C. B. Harley, and P. M. Lansdorp, "Evidence for a mitotic clock in human hematopoietic stem cells: loss of telomeric DNA with age," Proceedings of the National Academy of Sciences of the United States of America, vol. 91, no. 21, pp. 9857-9860, 1994.

[40] K. Huang, D. H. Zhou, S. L. Huang, and S. H. Liang, "Agerelated biological characteristics of human bone marrow mesenchymal stem cells from different age donors," Zhongguo Shi Yan Xue Ye Xue Za Zhi, vol. 13, no. 6, pp. 1049-1053, 2005.

[41] S. J. Morrison, A. M. Wandycz, K. Akashi, A. Globerson, and I. L. Weissman, "The aging of hematopoietic stem cells," Nature Medicine, vol. 2, no. 9, pp. 1011-1016, 1996.

[42] L. Berkahn and A. Keating, "Hematopoiesis in the elderly," Hematology, vol. 9, no. 3, pp. 159-163, 2004.

[43] K. Kuranda, J. Vargaftig, P. de la Rochere et al., "Age-related changes in human hematopoietic stem/progenitor cells," Aging Cell, vol. 10, no. 3, pp. 542-546, 2011.

[44] R. H. Cho, H. B. Sieburg, and C. E. Muller-Sieburg, "A new mechanism for the aging of hematopoietic stem cells: aging changes the clonal composition of the stem cell compartment but not individual stem cells," Blood, vol. 111, no. 12, pp. 5553-5561, 2008.

[45] P. Aroviita, K. Teramo, V. Hiilesmaa, and R. Kekomäki, "Cord blood hematopoietic progenitor cell concentration and infant sex," Transfusion, vol. 45, no. 4, pp. 613-621, 2005.

[46] R. Ray, N. M. Novotny, P. R. Crisostomo, T. Lahm, A. Abarbanell, and D. R. Meldrum, "Sex steroids and stem cell function," Molecular Medicine, vol. 14, no. 7-8, pp. 493-501, 2008.

[47] S. Abraham, S. Manjunath, S. Baskar et al., "Autologous stem cell injections for spinal cord injury-a multicentric study with 6 month follow up of 108 patients. 7th Annual Meeting of Japanese Society of Regenerative Medicine, Nagoya, Japan, 1314 March 2008. Saisei-iryo (Regenerative Medicine)," Journal of Japanese Society of Regenerative Medicine, vol. 7, supplement 1, 2008, abstract No O-13-7.

[48] K. M. Page, L. Zhang, A. Mendizabal et al., "Total colonyforming units are a strong, independent predictor of neutrophil and platelet engraftment after unrelated umbilical cord blood transplantation: a single-center analysis of 435 cord blood transplants," Biology of Blood and Marrow Transplantation, vol. 17, no. 9, pp. 1362-1374, 2011. 


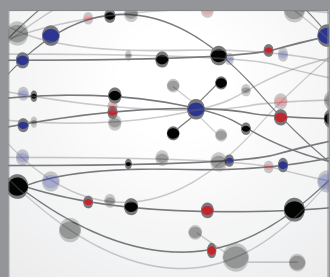

The Scientific World Journal
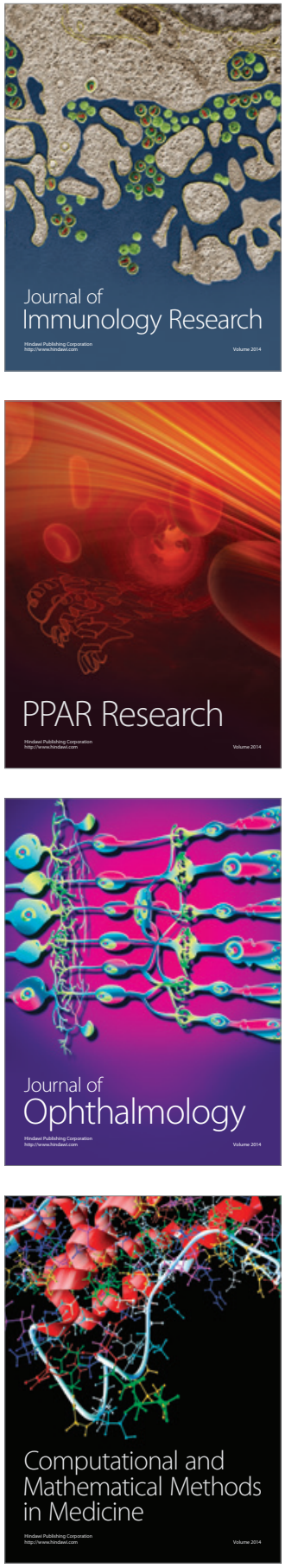

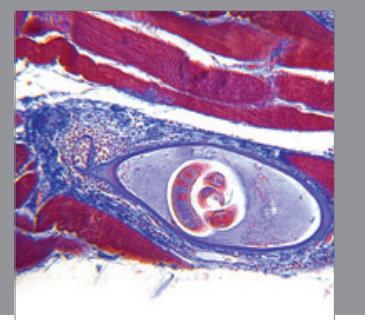

Gastroenterology

Research and Practice
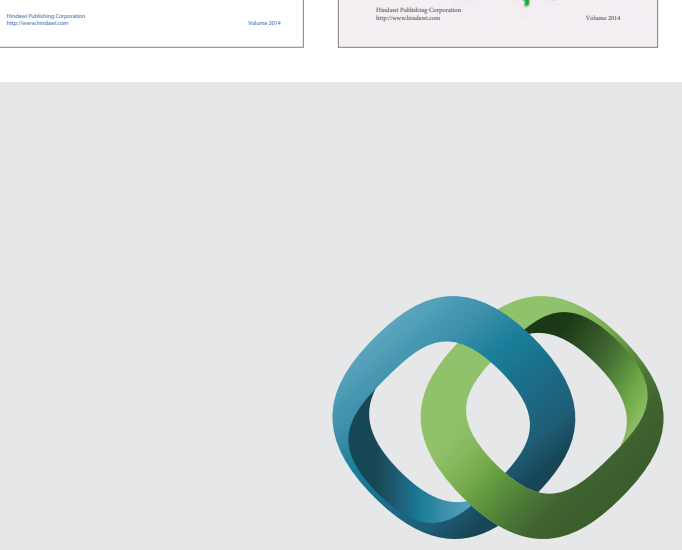

\section{Hindawi}

Submit your manuscripts at

http://www.hindawi.com
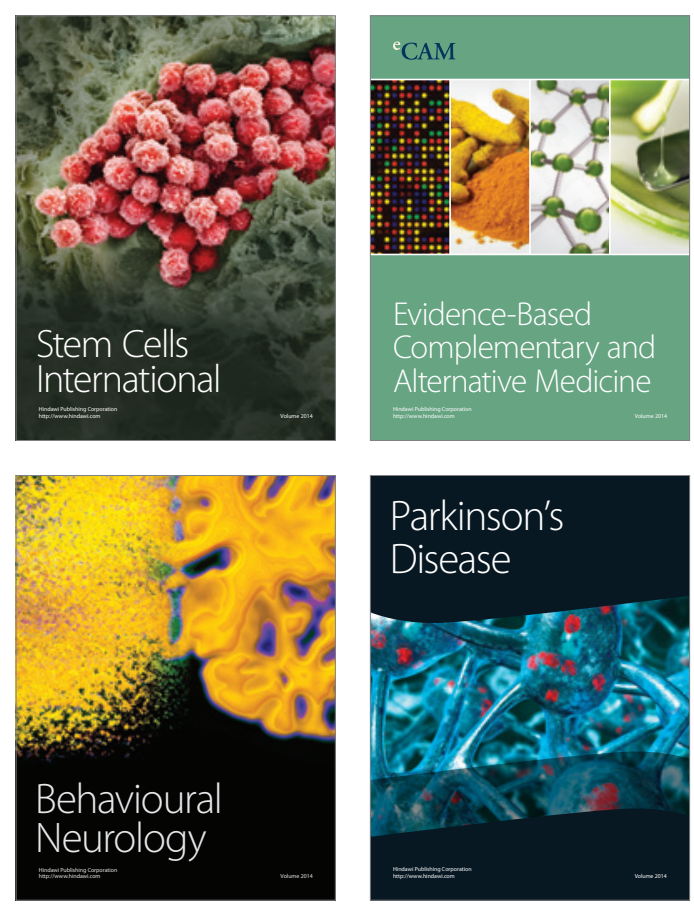

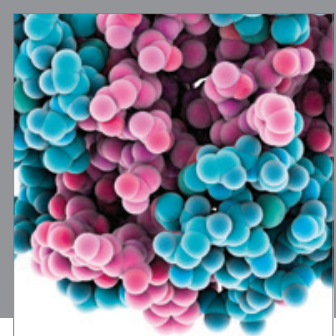

Journal of
Diabetes Research

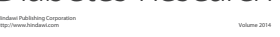

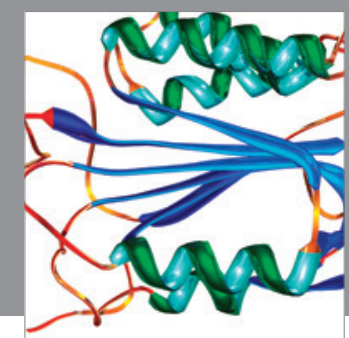

Disease Markers
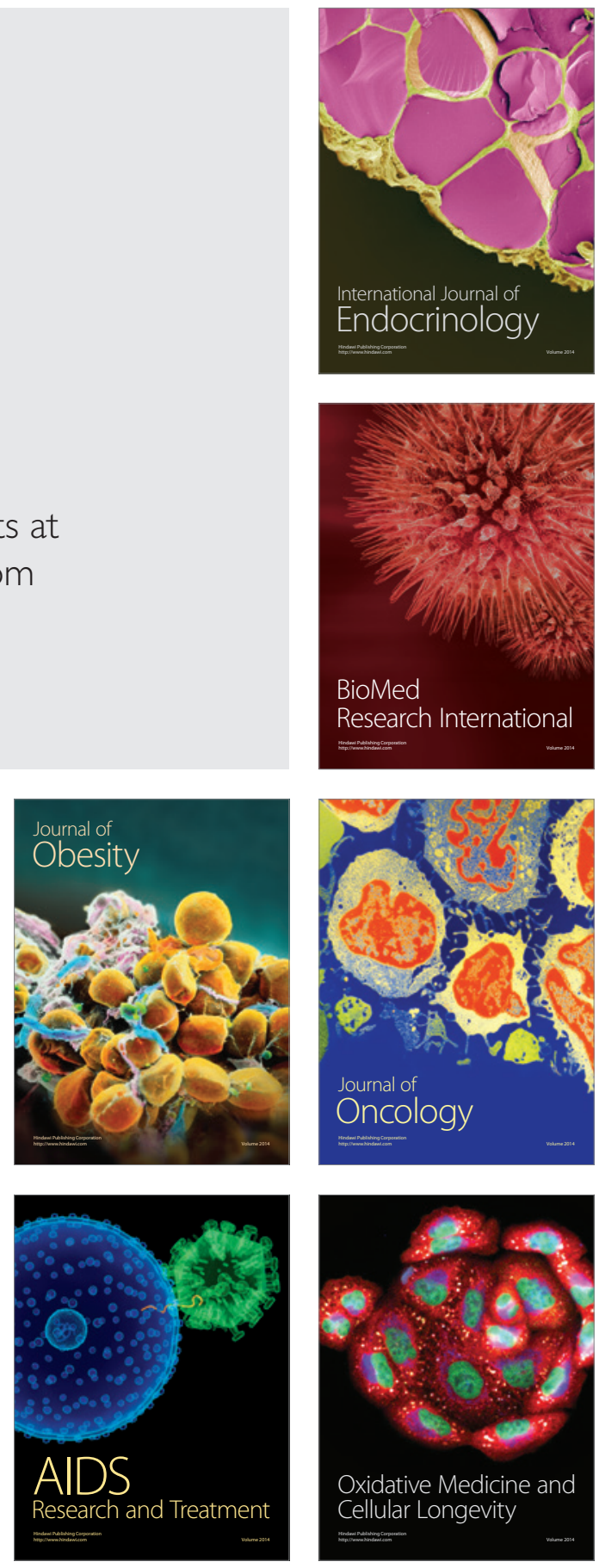